\title{
Correction to: Sputum ACE2, TMPRSS2 and FURIN gene expression in severe neutrophilic asthma
}

\author{
Nazanin Zounemat Kermani ${ }^{1,2 \dagger}$, Woo-Jung Song ${ }^{2,3 \dagger}$, Yusef Badi ${ }^{1,2}$, Ali Versi ${ }^{1,2}$, Yike Guo ${ }^{1}$, Kai Sun ${ }^{1}$, \\ Pank Bhavsar ${ }^{2}$, Peter Howarth ${ }^{4,5}$, Sven-Erik Dahlen ${ }^{6}$, Peter J. Sterk ${ }^{7}$, Ratko Djukanovic ${ }^{4,5}$, lan M. Adcock ${ }^{1,2}$ \\ and Kian Fan Chung ${ }^{1,2^{*}}$ (D) on behalf of U-BIOPRED Consortium
}

\section{Correction to: Respir Res (2021) 22:10.} https://doi.org/10.1186/s12931-020-01605-8

Following publication of the original article [1], we were notified that Fig $2 \mathrm{~b}$ and $2 \mathrm{c}$ were duplicated. Figure $2 \mathrm{c}$ should be the data from bronchial biopsy.

Also, in Additional Table S1, the values for Female Asthma and Control under Bronchial Brushing were swapped and the last table column should read "Bronchial biopsy" instead of "Bronchial Brushing".

*Correspondence: f.chung@imperial.ac.uk

${ }^{\dagger}$ Nazanin Zounemat Kermani and Woo-Jung Song contributed equally to

this work

${ }^{1}$ Data Science Institute, Imperial College London, London, UK

Full list of author information is available at the end of the article 


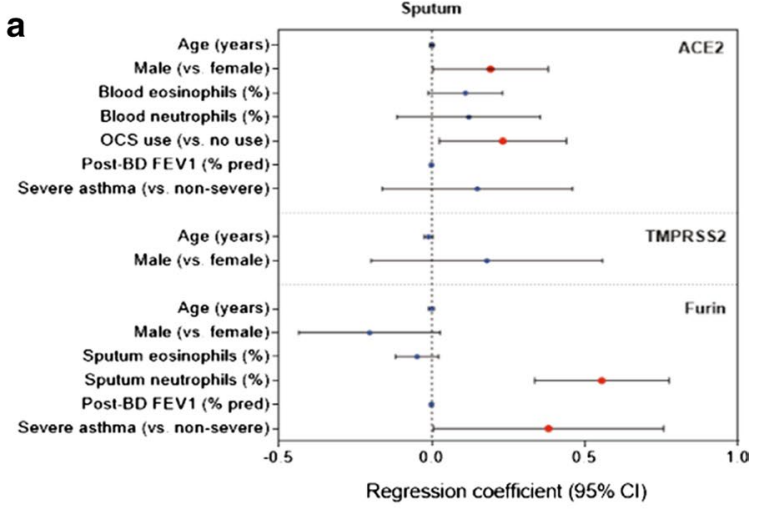

b
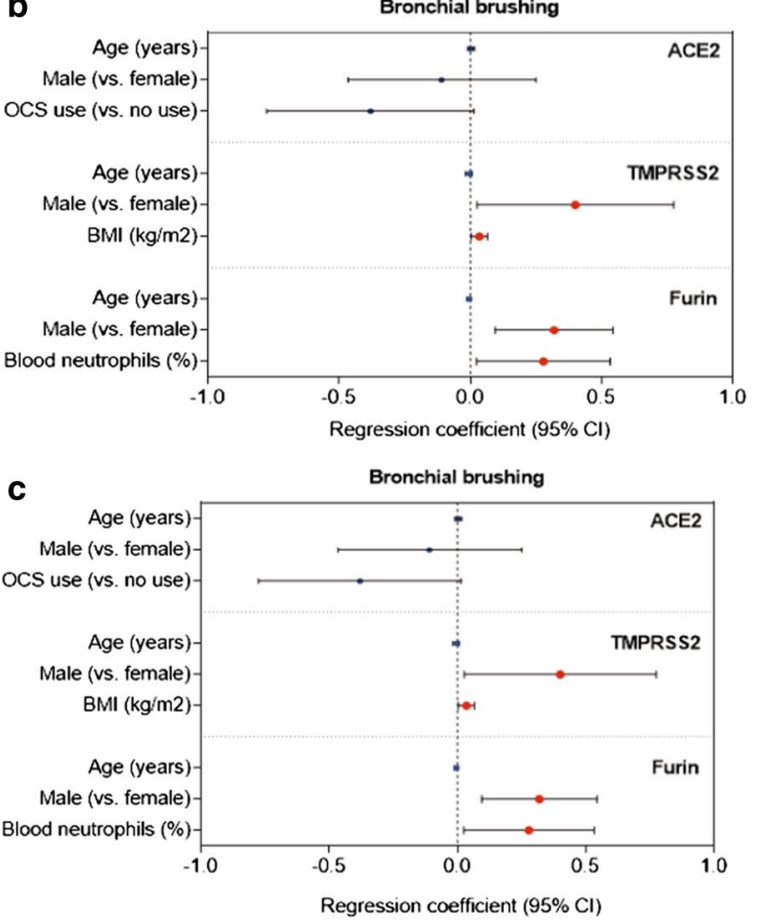

Originally published Fig. 2.

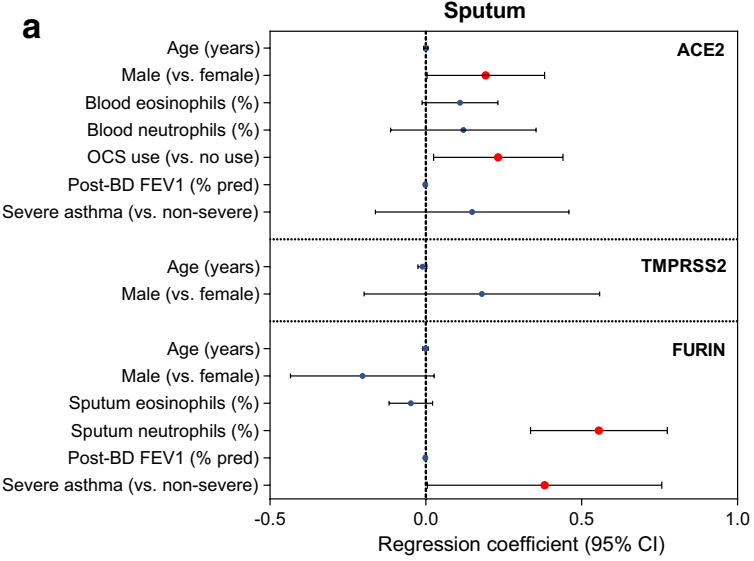

b

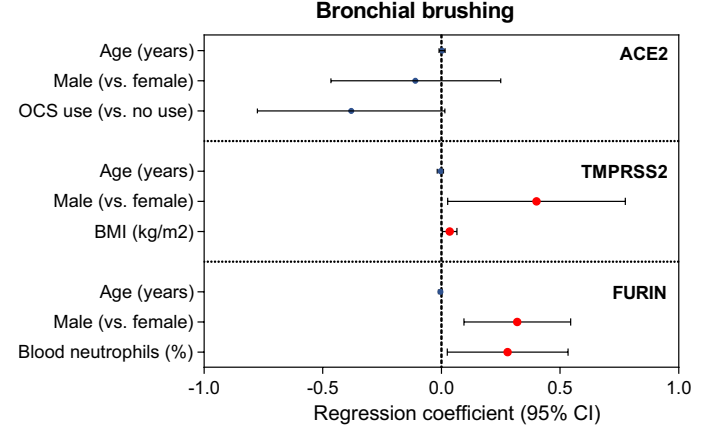

C

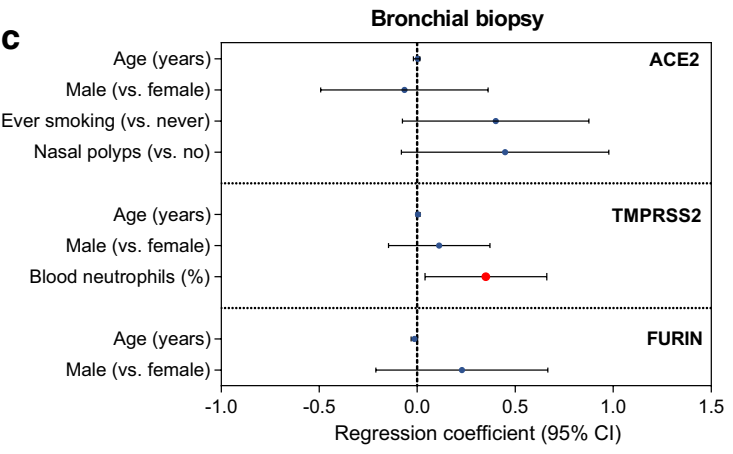

Corrected Fig. 2.

The original article has been corrected. 


\section{Author details}

${ }^{1}$ Data Science Institute, Imperial College London, London, UK. ${ }^{2}$ National Heart and Lung Institute, Imperial College London, Dovehouse St, London SW3 6LY, UK. ${ }^{3}$ Department of Allergy and Clinical Immunology, Asan Medical Center, University of Ulsan College of Medicine, Seoul, Korea. ${ }^{4}$ Faculty of Medicine, Southampton University, Southampton, UK. ${ }^{5}$ NIHR Southampton Respiratory Biomedical Research Unit, University Hospital Southampton, Southampton,

UK. ${ }^{6}$ Centre for Allergy Research, Karolinska Institute, Stockholm, Sweden.

${ }^{7}$ Amsterdam University Medical Centers, University of Amsterdam, Amsterdam, Netherlands.

Published online: 08 February 2021

\section{Reference}

1. Kermani ZK, Song W-J, Badi Y, Versi A, Guo Y, Sun K, Bhavsar P, Howarth P, Dahlen S-E, Sterk PJ, Djukanovic R, Adcock IM, Chung KF, on behalf of U-BIOPRED Consortium. Sputum ACE2, TMPRSS2 and FURIN gene expression in severe neutrophilic asthma. Respir Res. 2021;22:10. https://doi. org/10.1186/s12931-020-01605-8.

\section{Publisher's Note}

Springer Nature remains neutral with regard to jurisdictional claims in published maps and institutional affiliations.
Ready to submit your research? Choose BMC and benefit from:

- fast, convenient online submission

- thorough peer review by experienced researchers in your field

- rapid publication on acceptance

- support for research data, including large and complex data types

- gold Open Access which fosters wider collaboration and increased citations

- maximum visibility for your research: over $100 \mathrm{M}$ website views per year

At BMC, research is always in progress.

Learn more biomedcentral.com/submissions 